\title{
Can Expense Ratios Signal Performance? An Analysis of Equity ETFs \& Mutual Funds
}

\author{
James Monroe Gamble IV ${ }^{*}$ \\ Department of Economics, University of Missouri, Columbia, MO \\ bttps:/ / doi.org/10.33697/ ajur.2020.004 \\ Student:jmg2g2@mail.misssouri.edu* \\ Mentor:shastrisandy@gmail.com
}

\begin{abstract}
This study examines the impact of the emergence of exchange-traded funds (ETFs) as an alternative investment vehicle to mutual funds. As the number of ETFs continues to rise, we investigate potential risks and disadvantages posed by ETFs in comparison to traditional mutual funds. We compare the returns, performance, and expense ratios of ETFs to those of mutual funds. We find that expense ratios are positively correlated with actively managed mutual fund returns and that passive funds have outperformed active funds since their inception. There is downward pressure on mutual fund fees over time, suggesting increased competition between mutual funds and ETFs. We also find, up to a certain threshold, actively managed funds are worth their costs.
\end{abstract}

\section{KEYWORDS}

Exchange-Traded Fund (ETF); Mutual Fund; Investing; Fee Structure; Expense Ratio; Passive (Active) Investing; Portfolio Management; Indexing

\section{INTRODUCTION}

Innovations in financial products have shaped and reshaped how effective we are at investing. Exchange-traded funds (ETFs) are no exception. Their proliferation has brought diversification, top tier management, and sophisticated investment strategies to the retail investor. ${ }^{1}$ No longer do mutual funds have a stronghold on the market. From 2009 to 2018, index-based equity ETFs attracted roughly one and a half times the net flows of domestic equity index mutual funds (Figure 1). ${ }^{2}$ Investment decisions that once required a team of dedicated money managers can now be made with a few simple clicks of a mouse. Diversified asset classes in financials, consumer staples, or broad market indices are accessible to ordinary people without the need of a financial manager. This is significant as defined contribution retirement plans have begun to supplant defined benefit pension plans, placing more responsibility on individuals to manage retirement savings.

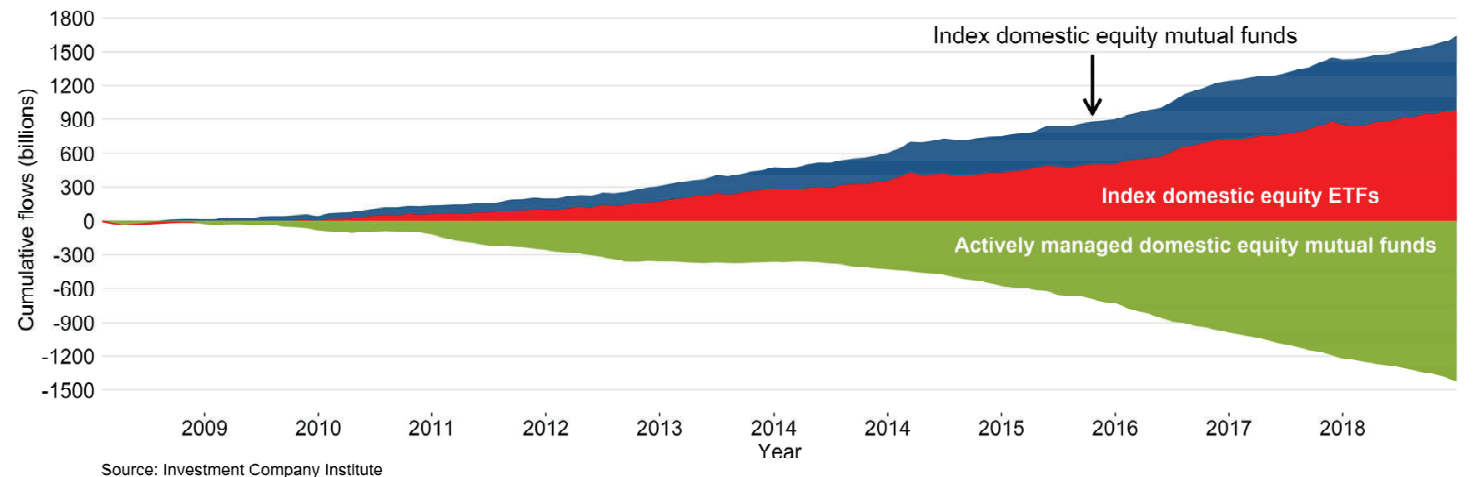

Figure 1. Mutual funds outflows have gone to ETFs. ${ }^{2}$

Cumulative flows to domestic equity mutual funds and net share issuance of domestic equity index ETFs; billions of dollars, monthly Mutual fund data include net new cash flow and reinvested dividends; ETF data for net share issuance include reinvested dividends. Before October 2009, domestic equity index ETF data include a small number of actively managed domestic equity ETFs.

ETFs compete with mutual funds for investor's money and are generally perceived to have sweeping benefits, such as liquidity and tax efficiencies. Innovations in financial technology (fintech) have democratized investing by making financial markets more accessible and lowering transaction costs. Increasingly, brokerage firms offer commission-free trades for ETFs allowing investors to avoid $100 \%$ of the trading costs and maximize returns. Fintech startup Robinhood disrupted the brokerage industry when it 
began offering commission-free trades. Robinhood's popularity has pushed other firms to adapt by lowering or removing commissions on select ETFs. As a result, most ETFs can be bought and sold by retail investors without transaction costs.

\section{Background}

Research examining the efficiencies of ETFs exists, but there is little study into the confluence of fee structures underpinning these investments and fund performance. ${ }^{3,4}$ With investment complexity comes the need for careful analysis to uncover not only the benefits but also the hidden costs to investors. Are ETFs better than mutual funds along characteristics such as fee and tax structures or performance as measured by long term returns on investment? Our study addresses this question.

For mutual funds, a wealth of research exists examining how management and fees affect value. Financial Planners, retail, and institutional investors can use our results to increase portfolio profitability for both retirement planning and capital growth. Investors, given an easy-to-implement investment technique with significant returns, can effectively manage their savings. Due to an overload of information and fear of making incorrect retirement investments, Americans frequently turn to professionals for advice. Commissions, kickbacks, and fees drawn from investor accounts create conflicts of interest. ${ }^{5}$ It is common practice for mutual fund providers to compensate brokers for attracting investors. Incentivized brokers may steer clients' savings into funds with higher fees and lower returns or suggest inappropriate rollovers out of low-cost retirement plans to generate commissions. The White House Council of Economic Advisers (CEA) estimates $\$ 17$ billion in losses every year to working and middle-class families due to poor investment advice. ${ }^{6}$

To combat the principal-agent problems that exist between brokers and their clients, the SEC adopted Regulation Best Interest (Regulation BI) in June of 2019. Regulation BI requires that broker-dealers put their client's interests first when recommending securities transactions or investment strategies. The SEC simultaneously adopted the Customer Relationship Summary (CRS) form, which requires brokers and registered investment advisors (RIAs) to state their roles clearly. ${ }^{7}$ Our research complements these reforms. We explore whether ETFs provide effective investment alternatives to mutual fund shares purchased through intermediaries. Investors can purchase ETFs directly, thereby avoiding fees charged by traditional mutual funds. These fees ultimately lower returns.

Factors such as tax and management expenses affect investors' per-share returns. For consistency, we focus on long-term capital gains, which are classified as investments of one year or more. In the United States, capital gains are taxed at different rates depending on income and term length. Capital gains on short-term investments, held for a year or less, are taxed as ordinary income. Long-term capital gains are taxed at maximum rates of $0 \%, 15 \%$, or 20\%, depending on the investor's total income. At all income levels, the maximum tax rate on long-term capital gains is less than the tax rate on ordinary income. Furthermore, qualified retirement plans can cause the income tax cost to be avoided altogether or drastically reduced. Individual Retirement Accounts (IRAs) and defined contribution 401(k) plans are common tax-deferred investment vehicles. In a tax-deferred IRA or 401(k), federal and state income taxes are deferred until funds are withdrawn in retirement. Then, withdrawals are taxed as ordinary income. Public and private employers offer these plans to employees, matching employee contributions anywhere from $0 \%$ to $100 \%$ after an initial vesting period. Other retirement accounts, such as Roth IRAs, allow after-tax income to be invested in accounts that allow tax-free withdrawals in retirement.

Understanding the effects of tax structures and transaction costs is important because investing is an exponential process. Small improvements in earnings can lead to substantial gains, while hidden costs hinder the growth of nest eggs and lengthen maturity dates. Over 35 years, one percentage point of lower returns could reduce savings by more than $25 \%$. With a four percent effective annual return, a $\$ 10,000$ retirement investment will grow to more than $\$ 39,000$. With a three percent return, it would be just over $\$ 28,000$, a reduction of $28.7 \%$. Our research will prove beneficial to those investing in both deferred and non-tax deferred accounts. ETFs offer the advantage of providing the diversification of a mutual fund with the liquidity of a stock, in addition to tax savings on reinvested dividends (Figure 2). A mutual fund must pay a capital gains tax on earnings, which is then compounded by a second tax on the investor. ETFs reinvest dividend payments or distribute them directly to shareholders, thus sparing this double taxation expense. 


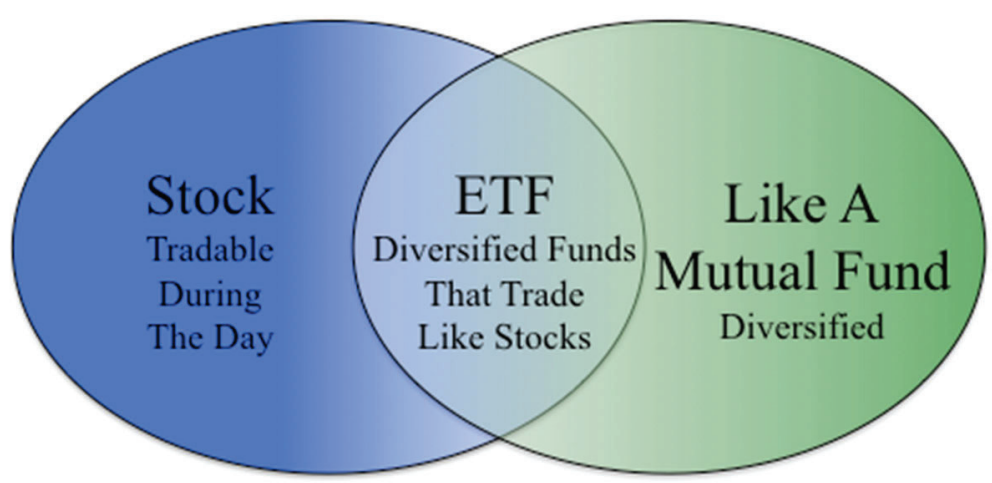

Figure 2. ETFs offer the liquidity of a stock and the diversification of a mutual fund.

Our findings are helpful to regulators making decisions on how to protect consumers best. The Securities and Exchange Commission (SEC) and the Financial Industry Regulatory Authority (FINRA) govern the types of fees that mutual funds and ETFs can charge. Fees such as $12 \mathrm{~b}-1$ fees, sales loads, and redemptions are regulated with caps on the amount funds can charge. ${ }^{10}$ However, many other hidden fees can be costly to investors. ETFs are one solution to simplifying fee structures as their fees can be represented by one number, the expense ratio.

Funds can be classified by their investment strategy. Actively managed funds try to beat the market while passive funds aim to mimic the performance of a benchmark index. In this study, we classify index-based strategies as passive. There has been an extensive debate on the merits of active versus passive management, but few studies have focused on the relationship between active and passive ETFs in addition to mutual funds. This is in part due to the infancy of ETFs. The first ETF listed on a US stock exchange was the Standard \& Poor's Depository Receipts (SPDR) introduced in 1993 by State Street Global Advisors. The fund tracks the S\&P 500 and trades under the ticker SPY. As of 2019, the SPDR S\&P 500 ETF Trust is the world's largest ETF with more assets under management (AUM) than the second and third largest ETFs combined. ETF growth was slow until the mid-2000s. In 2006, ETF growth began to accelerate. Between 2006 and 2019, growth in the number of listed ETFs surpassed 450\% (Figure 3). As of year-end 2018, there were 1,988 actively and passively managed ETFs in the US. In combination, USlisted ETFs account for $\$ 3.4$ trillion in total net assets and make-up $71 \%$ of the $\$ 4.7$ trillion held by ETFs worldwide. ${ }^{2}$

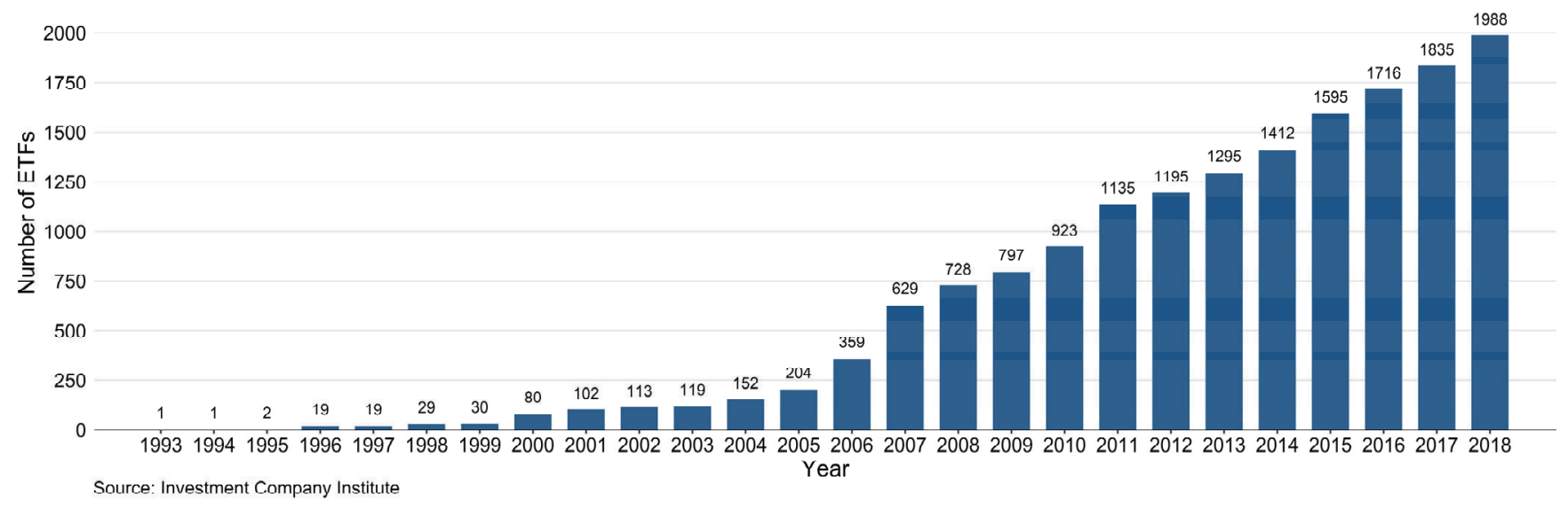

Figure 3. ETF growth in the United States between 1993 and 2019.

With growth comes complexity. Though the first passive ETF was introduced in 1993, it took fifteen years for active ETFs to emerge. In 2008, the Bear Stearns Current Yield Fund (YYY) became the first active US-listed ETF. The fund was doomed from the start as Bear Stearns was collapsing. Also, the fund's strategy was limited to trading short-term debt securities curbing managerial ability to generate high returns. ${ }^{11}$ Soon after, PowerShares introduced the Active Alpha family of funds, which debuted the first active equity ETFs. Each fund uses complex quantitative trading methodologies to select stocks. Since their introduction, the number of active ETFs has grown by over $200 \%$. As of year-end 2018, there are 289 actively managed ETFs. ${ }^{2}$

Our study is novel in that we categorize ETFs into active and passive investment strategies. The overwhelming majority of ETFs are index-based; however, actively managed ETFs are becoming increasingly common. The two approaches are fundamentally different and should be treated as such. There has been an extensive debate about the merits of active and passive management 
styles. We add to this literature by introducing ETFs into the debate. We compare active funds and passive ETF performance to the historical performance of mutual funds during the same period spanning 1993 to 2019. We break funds into one of four types: mutual fund active, mutual fund passive, ETF active, and ETF passive. Past studies that cast a wide net over all fund strategies and types obscure the costs and benefits of each.

We focus on singling out the relationship between high fees and performance, high fees being an indicator of fund success measured using the dollar percentage gain per share. High fees indicate success because an underperforming fund that charges high fees will have negative cash flows. To attract investment, funds must appeal to investors charging a price that the market will bear. Underperforming funds must lower fees or become insolvent, while outperforming funds will continue to operate compensated by the market accordingly. By breaking down the relationship between performance and management expenses, we can discover a pattern of successful funds and demonstrate the independence of a fund portfolio's underlying assets. Analysts typically spend a lot of time and resources investigating these properties. We streamline this information search by basing evaluations solely on a fund's expense ratio and the performance it predicates.

\section{Literature Review}

Our paper contributes to the literature on ETFs and mutual funds as investment vehicles. Guedj and Haung investigate whether an ETF is a more efficient indexing vehicle than an open-ended mutual fund (OEF). Examining organizational structure via an equilibrium model, Guedj and Haung show that OEFs are beneficial to risk-averse investors due to partial insurance against liquidity shocks embedded in the fund's structure. They also find that OEF structures create moral hazard problems inducing excessive trading. Overall, they find that transaction costs to all investors are the same in OEFs and ETFs, though the allocations of these costs differ. Guedj and Haung conclude that investors with similar liquidity needs should be indifferent between the two fund types. ${ }^{3}$

Poterba and Shoven examine the perception of ETFs as tax-efficient alternatives comparing the pre-tax and post-tax returns of the largest ETF, the SPDR S\&P 500 Trust (SPY), with the returns of the largest equity index fund, the Vanguard 500 Index Fund. They find that between 1994 and 2000, the after-tax performance of the two funds are very similar. ${ }^{4}$ Poterba and Shoven do not examine other ETF or mutual fund alternatives. This is of concern because assets held by SPY account for less than $7.8 \%$ of the passive ETF marketplace. ${ }^{A}$ The timing of Poterba and Shoven's study precludes a considerable increase in ETF offerings. We include in our study a representative sampling of funds offering diverse strategies, objectives, and goals.

Poterba and Shoven have found that ETFs may be more attractive for equity investments outside of tax-deferred accounts than IRAs or $401(\mathrm{k}) \mathrm{s}$ due to their low rate of taxable distributions and liquidity. Conversely, retirement account investors may find traditional equity mutual funds more attractive due to their unique tax attributes. ${ }^{4}$ Poterba and Shoven do not go beyond SPY in their analysis of ETFs, raising the issue of sample size. Our study builds on their examination of after-tax returns encompassing a larger body of ETFs and traditional funds. Poterba and Shoven account for two passive funds to the exclusion of the broader ETF and conventional fund market, which includes both active and passive strategies. Due to the timing, their study excludes innovations in the ETF and mutual fund market. In 2001, there were 102 ETFs, far fewer than the number available in today's marketplace.

For regulators addressing retirement savings, ETF investment strategies can counteract future uncertainties of social programs, such as Social Security, which are increasingly under the pressure of ballooning deficits. State pension fund managers will also find this work beneficial as they may spare many unnecessary search costs and expenses charged by brokers and hedge funds. Society's capitalized cost of price discovery is at least $10 \%$ of the current market cap. It has been estimated that individual returns would be increased by 67 basis points if every investor switched to a passive market portfolio. ${ }^{12}$

Chung et al. study the relationship between hedge fund manager compensation and ability, determining managers receive compensation in relation to their ability. ${ }^{13}$ An explicit pay structure is coupled with an implicit measurement to determine management compensation. A manager's ability to generate future cash flows is indicative of the manager's current ability. Therefore, managers who can generate more cash flow will receive higher levels of compensation because these managers earn fees on larger funds. Because there is a link between performance and compensation, we predict higher mutual fund fees will correlate to increasing levels of fund performance as fees are paid to managers by willing investors eager to compensate high caliber managers for higher returns. Work linking hedge fund and mutual fund performance with compensation has been performed by Holmstrom, Berk and Green, Berk and Van Binsbergen, and Lim, Sensoy, and Weisbach. ${ }^{14-17}$

\footnotetext{
A As of September 05, 2019. Assets under management change dynamically.
} 


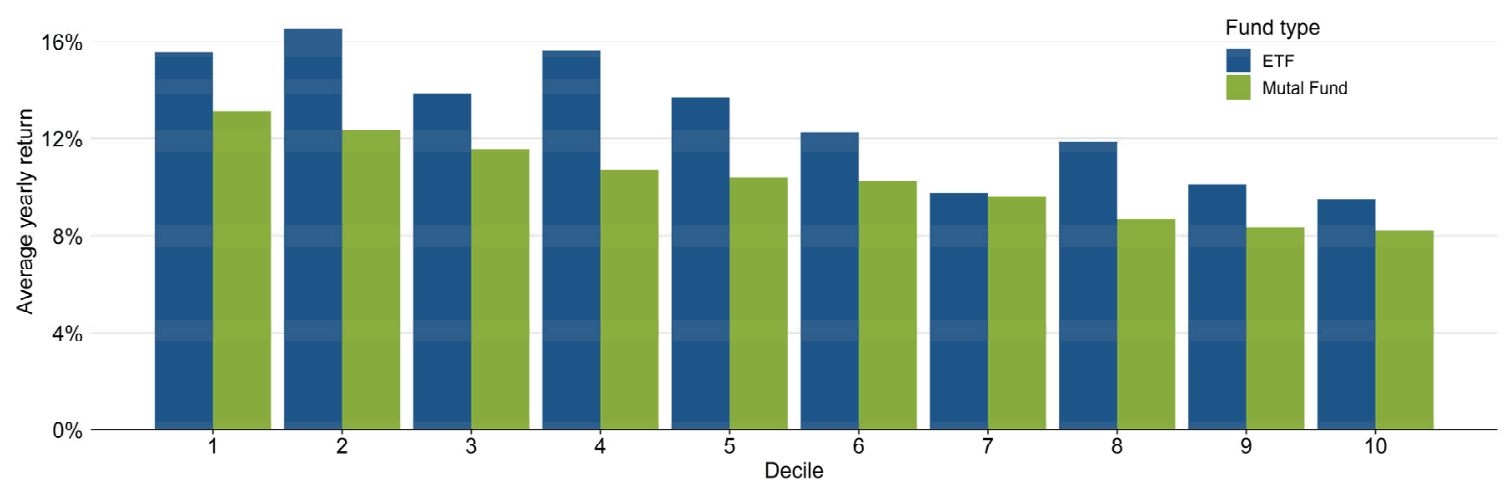

Figure 4. Displays the relationship between expense ratios and returns using the average yearly change in net asset value (NAV).

Mutual fund and ETF expense ratios represent the percentage of a fund's total assets used to operate the fund. These fees are automatically deducted from a fund's assets by managers. We use changes in a fund's net asset value (NAV) to measure an investor's returns. NAVs are computed net of all expenses taken out by fund managers. Figure 4 shows that both mutual fund and ETF performance decrease as their expense ratios increase. The best performing funds have low-cost structures, while the high-cost funds exhibit the worst performance. This is likely attributable to the fact that low-cost funds generally use index-based strategies that require less decision making and turnover (percentage of holdings that change over a year) lowering costs.

Figure 5 paints a more detailed picture. Again, we display the relationship between fund expense ratios and performance. However, this time we categorize by fund type and investment strategy. Though these results are far from conclusive, Figure 5 offers three important insights that lead us to believe that funds should be categorized by strategy instead of lumping them together by fund type as past studies have done.

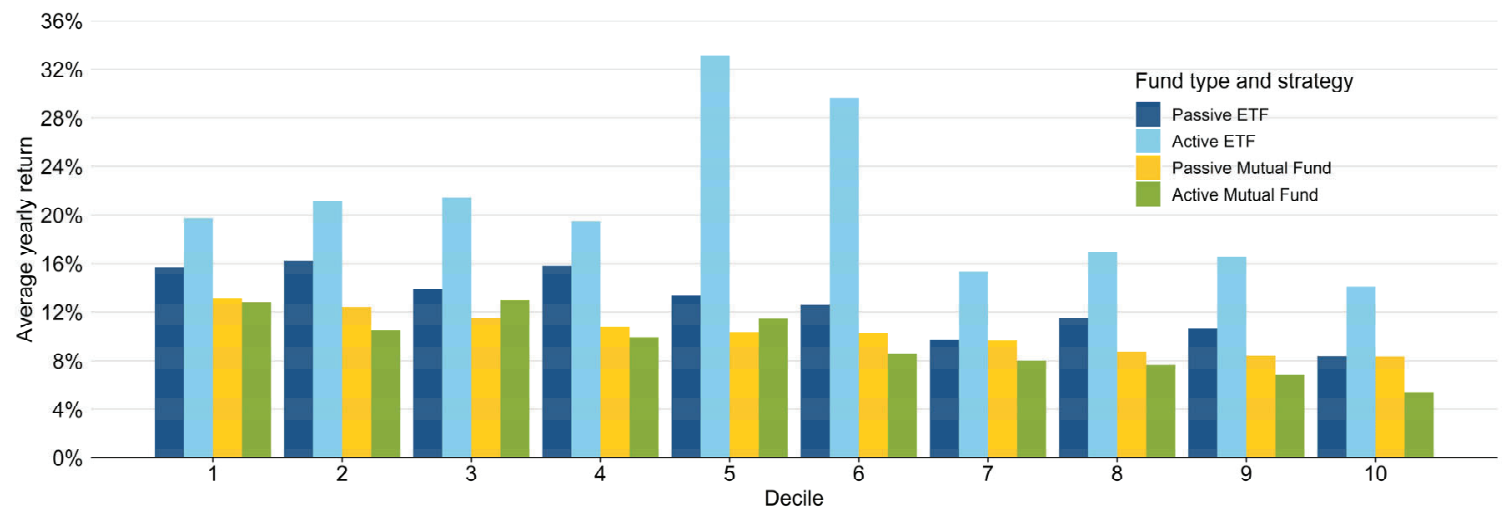

Figure 5. Expense ratio on fund performance by fund type and strategy.

First, active ETFs' change in NAV increases as the fund's expense ratio increases. Performance peaks at the fifth decile, but performance is still high at the sixth decile before dropping by nearly $50 \%$. Passive ETFs do not appear to penalize for higher expense ratios until the fifth decile. From this, we gather that a positive relationship will only hold up to a certain threshold that differs by fund type and strategy. For funds with higher expense ratios, managers are unable to overcome the higher costs with improved performance.

Second, passive funds provide consistent returns. Passive fund performance varies less when compared to active funds. For mutual funds, excluding deciles three and five, passive strategies outperform active strategies. Passive ETFs outperform both mutual fund strategies across all decile groups. This, in conjunction with the performance of active ETFs, suggests ETFs may have an advantage over mutual funds. Although in the seventh and tenth decile, passive ETFs only slightly outperform passive mutual funds.

Third, eventually, all funds succumb to the behavior displayed in Figure 4. Higher expense ratios lead to lower returns. This is particularly true for index-based funds whose performance does not change as expense ratios increase. Because passive funds mimic major-indices, the composition of funds held by tenth decile funds is the same as those held by lesser decile funds. It 
follows that index-based funds with higher fees will always perform worse than their lower fee equivalent. Investment in these funds contradicts rational expectations theory. However, behavioral economists have sought to explain why investors purchase high-fee index funds in lieu of a low-cost equivalent, finding that susceptible investors overweight funds' past performance and that this behavior decreases with financial literacy. ${ }^{18}$

Overall, we find that ETFs outperform mutual funds across investment strategies and that passive investment strategies perform well relative to active strategies. These findings are far from conclusive. Pástor, Stambaugh, and Taylor have found decreasing returns to scale in the active mutual fund industry. Over time they find that fund performance deteriorates at both the fund and industry level. They also find that young funds tend to outperform older funds. It is possible that we may see the same thing happen to active ETFs. As the active ETF market becomes more crowded, average performance will likely decrease over time. ${ }^{19} \mathrm{It}$ is also possible that outliers may skew performance though we find similar results after winsorizing the top and bottom $10 \%$ of funds by expense ratio and NAV. Active ETFs are particularly susceptible due to the relatively small number of active ETFs relative to other funds.

We observe fierce competition in the industry, with mutual fund fees steadily declining since 2003 (Figure 6).

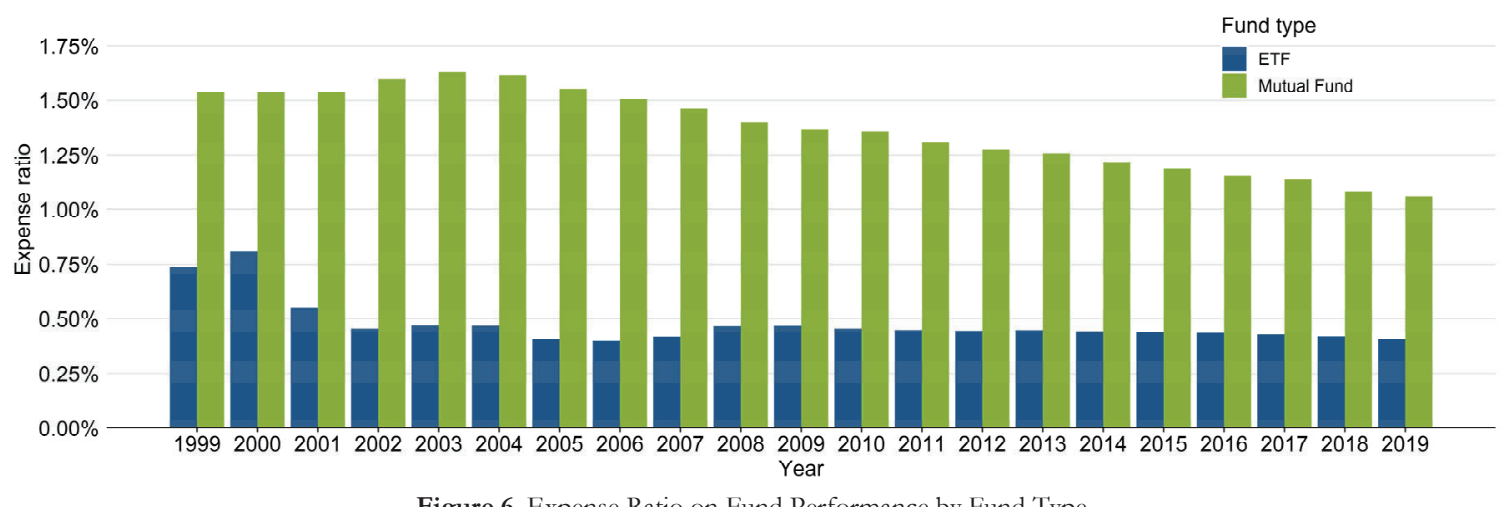

Figure 6. Expense Ratio on Fund Performance by Fund Type.

As Robinhood has transformed the brokerage industry, ETFs are having a similar effect on mutual funds. Some of the largest mutual fund companies offer ETF versions of their most popular funds allowing investors to avoid front-end loads and initial minimum investments. For example, Vanguard offers its most popular fund, the Vanguard 500 Index Fund, as the Vanguard S\&P $500 \mathrm{ETF}$ (VOO).

Mutual funds emulating indices have experienced inflows, while outflows from active mutual funds have accelerated (Figure 1). We predict, due to competition, increased transparency, and lower barriers to entry, that mutual fund and ETF management fees will be driven toward convergence. Hortaçsu and Syverson discuss the dispersion of fund fees amongst S\&P 500 index funds finding that search costs largely drive differences in fees, product differentiation via marketing, and competition. ${ }^{20}$ All three mechanisms have changed since the release of their paper in 2004. As seen in Figure 6, we find that mutual fund fees peaked in 2003 a year before the release of their findings.

\section{METHODS AND PROCEDURES}

Data and Variable Definitions

We use the Center for Research in Security Prices (CRSP) Survivor Bias-Free Mutual Fund Database for our analysis. ${ }^{21}$ The data

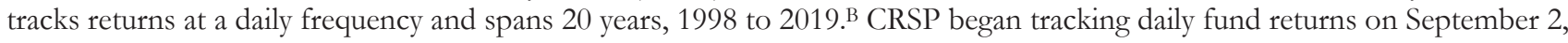
1998. The first observation in our dataset is from October 1, 1998. For periods prior, fund data is monthly, so we choose to focus on the later period. We measure fund performance using the change in net asset value. NAVs include reinvested dividends and subtracts management expense and $12 \mathrm{~b}-1$ fees. ${ }^{10}$

$$
\text { Net Asset Value }=\frac{\text { Assets }- \text { Liabilities }}{\text { Shares Outstanding }}
$$

Fee tables can be found in a fund's prospectus, which is an important document detailing a fund's investment objectives, risk, fees, expenses, and other pertinent information. The fees we focus on in our analysis are "Annual Fund Operating Expense." As defined by the SEC, this section lists management fees, distribution and service (12b-1) fees, other expenses, and total annual

B October 1, 1998 - July 28, 2019 
fund operating expenses. Expenses under the heading "Shareholder Fees" are excluded from a fund's expense ratio. These are fees such as sales loads, redemption, purchase, exchange, and account fees. These costs are excluded from the analysis because they depend more on investors' actions than on managers' choices. Also, because ETFs are traded on exchanges, to acquire these assets, investors must go through a stockbroker. Brokerage fees are classified as transaction costs and are excluded from our analysis. Long term, these fees are marginal and have no relationship to ETF performance. Shareholder fees vary by fund. The SEC does not impose specific limits on fees that a mutual fund may charge. The SEC does limit redemption fees to $2 \%$ in most situations; however, FINRA is mostly in charge of imposing limits on mutual fund fees. ${ }^{10}$

Turnover is a proxy for management expenses located within the "Annual Fund Operating Expense." Turnover tracks the number of trades made by a fund. The more trades, the higher the expense to the investor, as brokerage fees and commissions must be paid to intermediaries. Portfolio turnover is calculated per period by deducting from newly purchased securities the number of securities sold and dividing this number by the fund's NAV.

$$
\text { Turnover }=\frac{\text { Newly Purchased Securities }- \text { Securities Sold }}{\text { Net Asset Value }}
$$

ETFs reflect management costs in the expense ratio and are not subject to front or back end loads. Actively managed funds tend to incur more of these expenses as managers trade in and out of positions as the market fluctuates. Passive funds are designed to do the opposite, minimizing trading costs through strategies such as indexing. ${ }^{15}$ The minimization of turnover helps lead to lower expense ratios and other expenses. Fees and expenses vary by fund. A fund with high costs may perform better than a low-cost fund and still generate a smaller return. Small differences in fees translate into significant differences in returns over time.

Poor performing funds are more likely to exit the market creating an upward bias in performance as only the survivors remain.22-25 By including active and inactive funds, our dataset controls for this. A weakness of the CRSP dataset is that it does not control for incubation bias. Incubation bias occurs when firms utilize a series of privately held funds from which they handpick the best performers to offer publicly. During the incubation phase, funds accrue performance histories that are used in the fund's prospectus to increase the fund's marketability. CRSP reports performance from the incubation period, so the selection of incubation survivors leads to an upward bias. Only the past histories of strong funds are included in the dataset. Richard Evans has shown that this bias can be eliminated by excluding fund data from the incubation period. ${ }^{26}$ We do this by excluding fund data from before the public start date.

We limit our study to domestic equity mutual funds with an average of $90 \%$ or more of their assets in common stocks over their lifespan. Using the CRSP Style Codes, we exclude fixed-income funds and funds classified as "other" from our analysis. CRSP Style Codes consists of up to four characters that, from left to right, represent an increasing level of granularity. We restrict the first character to ' $\mathrm{E}$ ' for equity funds. Fixed income and money market funds are excluded from our analysis because we want to measure a fund manager's ability to pick stocks. We create flag variables for fund characteristics. We differentiate ourselves from other studies by focusing on fund type and investment strategy. Investment strategy consists of active and passive management styles and fund type differentiates ETFs from mutual funds.

Passively managed funds can be identified using CRSP's index fund flag; however, this data was not tracked until 2003. Other variables such as fund ticker, objective code, or ETF flag are not uniformly reported across each fund's identification number. We find that CRSP's summary data for a variety of reasons is missing or elects not to fill in certain fund characteristics. To correct for inconsistencies, we use a backward matching algorithm allowing us to fill in missing observations that go unreported for a portion of a fund's history. Using data from First Bridge, we can match Active ETFs by ticker. ${ }^{27}$ For example, by applying our matching algorithm to the index fund flag, we can identify index funds prior to 2003 if they existed after. To catch funds that existed before 2003, but not after, we use regular expressions to perform textual analysis on fund names to identify passive investment styles. For example, the terms "S\&P," "Dow Jones," "Russell," "Wilshire," or "MSCI" identify funds whose strategies are index-based. Similarly, ETFs can be flagged using backward matching on CRSP's ETF flags and then double-checked using textual analysis. We try a variety of identification schemes to cross-validate our results. Our most reliable indicator of fund type is the NASDAQ ticker. Tickers are widely issued across the entire sample and mutual funds can be identified using the fifth-letter, which is an X indicating that the fund is a Mutual Fund Quotation Service Instrument (MFQS). ${ }^{28}$

Funds with negative or zero expense ratios are removed from our sample. We consider all three of CRSP's index fund classifications as passive: pure index, index-based, and index enhanced. This creative approach allows us to widen the scope of our study to include four groups: active ETFs, passive ETFs, active mutual funds, and passive mutual funds. Expense ratios are reported as of the most recently completed fiscal year. We then allocate the costs over trading days to compute the average daily expense ratio for each fund. A fund's total expense ratio (TER) is calculated by multiplying its expense ratio by the fund's total assets. Expense ratios account for size differences amongst funds allowing us to make comparisons across firms. In absolute 
terms, a fund's total cost is attributable to its size. We further classify our data by computing fund age and creating an indicator for survivorship.

\section{Analysis}

The dependent variable in our model is returns. Daily and monthly returns are calculated as the change in NAV, including reinvested dividends. NAVs are net of all management expenses and 12b-1 fees. Front and rear load fees are excluded. Each day a total adjustment factor is calculated by CRSP. The adjustment factor begins with a value of one for each day and is then modified depending on the types of dividends found for the fund that day. Modifications include distributions, reinvestments, and stock splits. We use the daily adjustment factor calculation as specified by the CRSP Survivor-Bias-Free US Mutual Fund Guide. ${ }^{29}$

The independent variable of interest is management expense. For this variable, we use the net expense ratio provided by the CRSP Survivor-Bias-Free US Mutual Fund Database. The annual net expense ratio, often referred to as the "audited expense ratio," is drawn from a fund's audited annual report and is calculated as the percentage of a fund's assets paid during a fiscal year for operating expenses and management fees. Fees include accounting, administrator, advisor, auditor, board of directors, custodial, distribution (12b-1), legal, organizational, professional, registration, shareholder reporting, subadvisor, and transfer agency expenses. Waivers and reimbursements are included in the net expense ratio, while brokerage costs and investor sales charges are excluded. Annual expense ratios may differ from the prospectus expense ratios, as the annual ratio reflects a fund's actual expense, while the prospectus ratio is an estimate of expenses for the current period. ${ }^{30}$

We also include in our analysis control variables to capture the influence of external factors that can affect returns independent of managerial skill. If the economy is in an expansion, a manager may appear to possess more skill though increases in asset prices are attributable to growth in the broader economy. Interactions among control variables are permissible if all the interacting terms are included in the model. ${ }^{31}$ Coming up with a comprehensive list of outside factors influencing asset prices is not realistic. However, there is a method for calculating risk-adjusted returns that spares us from introducing thousands of control variables.

In 1993, Eugene Fama and Kenneth French identified three factors that explain up to 95\% of a diversified portfolio’s returns. ${ }^{32}$ These factors are firm size, book-to-market value, and excess returns on the market. These factors are commonly referred to as "Fama-French Factors" or the "Three-Factor Model". ${ }^{33}$ In 1997, Mark Carhart extended the model by adding momentum as a fourth factor. ${ }^{19}$ Thus, we use risk-adjusted returns to evaluate a manager's performance. We follow standard conventions small minus big (SMB), high minus low (HML), risk-free rate using the one-month Treasury Bill rate (RF), excess return on the market (MKTRF), and momentum (UMD). ${ }^{24}$ The first three factors are constructed using six value-weight portfolios formed on size and book to market equity ratio. The portfolios are classified as small value, small neutral, small growth, big value, big neutral, and big growth. This data can be found on Kenneth French's website. ${ }^{33}$ We use a compilation of these values provided by Wharton Research Data Service (WRDS). ${ }^{34}$ Below, we provide a high-level overview of our model. For more detail on the construction of the six portfolios, see Fama and French, "Common Risk. Factors in the Returns of Stocks and Bonds.",33

$$
\text { Excess Portfolio Returns } s_{i, t}=\propto+\beta_{1} M K T R F_{i, t}+\beta_{2} S M B_{i, t}+\beta_{3} H M L_{i, t}+\beta_{4} U M D_{i, t}+\varepsilon_{i, t}
$$

Excess portfolio returns or "risk-adjusted returns" are calculated as a fund's return minus RF. MKTRF is based on the valueweighted return of all CRSP firms incorporated in the US and listed on the NYSE, AMEX, or NASDAQ that have a CRSP share code of 10 or 11 at the beginning of month $t$, good shares and price data at the beginning of $t$, and good return data for the entire month. From this value, we subtract the return on riskless assets represented using the one-month Treasury bill (i.e. the risk-free rate, RF) from Ibbotson Associates. ${ }^{35}$ We refer to MKTRF and the market interchangeably as MKTRF. MKTRF is intended to be representative of the overall market.

$$
\begin{aligned}
& \text { Excees Portfolio Return }{ }_{i, t}=\text { Fund Return }_{i, t}-R F_{i, t} \\
& M_{K T R F_{i, t}}=\text { Market Return } n_{i, t}-R F_{i, t}
\end{aligned}
$$

Each factor has a coefficient or loading. The market portfolio loading, $\beta_{1}$, captures systematic risk by measuring the extent to which a fund's returns are attributable to changes in the broader market. A beta greater than one, e.g. 1.5 , means that for every 1 unit increase in the MKTRF the fund's returns will increase by 1.5 units. Conversely, a one-unit decrease would equate to a 1.5 unit decrease in the fund's returns. Thus, the fund is more sensitive to changes than the broader market and carries more systemic risk. The average firm has a beta of 1.0 meaning it moves with the market. A beta less than one means that a fund carries less systematic risk than average and a beta of zero equates to no systemic risk, i.e. the fund's performance is unaffected by the market. A negative beta means that the expected return of a fund moves in a direction opposite the expected return of the market portfolio. Most equity-only funds have betas close to $1.0 .^{36}$ Intuitively, higher betas equate to higher than expected returns as 
investors are taking on more risk. This intuition underlies the capital asset pricing model (CAPM) which measures a fund's risk relative to the market. In our model, we subtract RF from both sides giving us excess portfolio return on the left-hand side.

$$
\begin{gathered}
\text { CAPM: Fund Return } n_{i, t}=R F_{i, t}+\boldsymbol{\beta}_{\mathbf{1}} M K T R F_{i, t}+\varepsilon_{i, t} \\
\text { Fund Return } n_{i, t}-R F_{i, t}=\boldsymbol{\beta}_{\mathbf{1}} M K T R F_{i, t}+\varepsilon_{i, t}
\end{gathered}
$$

We estimate a single-factor market model as:

$$
\text { Excess Portfolio Return }_{i, t}=\propto+\varphi_{1}{\text { Expense } \text { Ratio }_{i, t}+\beta_{1} M K T R F_{i, t}+\varepsilon_{i, t}}
$$

In Equation 1, the intercept alpha $(\propto)$ is interpreted as the value added by a fund manager. After accounting for the expense ratio, alpha tells us how well the manager is performing relative to the market. An alpha of zero suggests a manager is capturing market returns perfectly, while a positive alpha suggests that the manger is delivering returns higher than the market's expected return. To evaluate a fund manager's ability, we subtract the portfolio's actual return from the benchmark return. If alpha is negative, the manager is underperforming the market.

$$
\alpha_{i, t}=\text { Excess Portfolio Return }_{i, t}-M_{K T R} F_{i, t}
$$

We estimate Fama-French 3-Factor and Carhart 4-Factor models:

$$
\begin{array}{rr}
\text { Fund Return }_{i, t}-R F_{i, t}=\propto+\varphi_{1} \text { Expense Ratio }_{i, t}+\beta_{1} M K T R F_{i, t}+\beta_{2} S M B_{i, t}+\beta_{3} H M L_{i, t}+\varepsilon_{i, t} & \text { Equation } 2 . \\
\text { Fund Return }_{i, t}-R F_{i, t}=\propto+\varphi_{1} \text { Expense Ratio }_{i, t}+\beta_{1} M K T R F_{i, t}+\beta_{2} S M B_{i, t}+\beta_{3} H M L_{i, t}+\beta_{4} U M D_{i, t}+\varepsilon_{i, t} & \text { Equation } 3 .
\end{array}
$$

$\mathrm{SMB}$ is the average return on the three small portfolios minus the average return on the three big portfolios. It accounts for the outperformance of small companies relative to large ones. Its loading, $\beta_{2}$, indicates the extent to which excess returns are attributable to its size. An SMB loading of zero signifies that a fund is primarily composed of large-cap stocks, while a value greater than 0.5 indicates a fund is tilted toward small-cap stocks. A statistically significant coefficient with a high $\mathrm{R}$-value indicates that the excess return of a fund may be attributable to its large size. ${ }^{36}$

HML is the average return on the two value portfolios minus the returns on the two growth portfolios. It encapsulates the historical excess returns to value stocks (high book-to-price ratio) over growth stocks (low book-to-price ratio). Its loading, $\beta_{3}$, represents the portion of excess returns that are attributable to its book-to-market equity value. A loading of zero implies a growth portfolio, while a loading of more than 0.3 implies the fund is tilted toward value stocks.

The fourth factor, UMD, was added by Mark Carhart and is calculated as the difference of the equal-weighted average of the lowest-performing funds and the equal-weighted average of the highest performing funds. Carhart found that returns for the previous 12-months can have predictive value on the future performance of that stock. A positive and statistically significant coefficient $\left(\beta_{4}\right)$ equates to positive momentum. ${ }^{24}$ Epsilon represents firm-specific risk. This is the part of the return that is unexplained by the factors.

We then add in fund controls:

$$
\text { Excess Portfolio Return }_{i, t}=\propto+\varphi_{1} \text { Expense Ratio }_{i, t}+\gamma_{2} \text { F Factors }_{i, t}+\gamma_{3} \text { Fund Controls }+\varepsilon_{i, t}
$$

Equation 4.

We then compare these equations to evaluate the relationship between performance and fees. In Equation 1, we use a single factor model upon which we expand to three and four-factor models, Equations 2 and 3. Eugene Fama and Kenneth French showed that the average explanatory value (r-squared) went from explaining $70 \%$ to $95 \%$ when moving from CAPM to three factors. ${ }^{32}$ Carhart later demonstrated that past performance could be used to explain future performance introducing momentum as a fourth factor.

Since Carhart's findings, other factors have been used; however, size, value, and momentum are universally accepted in the finance literature. In Equation 4, we add fund controls for daily net asset value (DNAV), total net asset value (TNAV), and turnover. Equations 2, 3, and 4 include our explanatory variable, the expense ratio. This allows us to compare alphas between equation parings. If a fund's performance is attributable solely to factors, then the manager has not demonstrated an ability to add value. High performing managers should enhance performance through the selection of stocks that outperform expected returns. We proxy a manger's value added by their ability to charge a fee for their stock-picking ability. The more a manager charges, the 
more value they should be able to demonstrate through superior returns. We expect high performing managers to have positive and statistically significant $\varphi_{1}$ values.

If a fund's alpha improves positively with the manager's compensation, we conclude that the improvement is attributable to the manager's ability to select stocks. Ordinary least of squares regressions are used to assess the relationship between independent and dependent variables. We use robust standard errors and include year and time fixed effects to account for differences across funds and years.

\section{RESULTS}

In Table 2, we present descriptive statistics of our data.

\begin{tabular}{|c|c|c|c|c|c|c|c|c|c|}
\hline Group & Observations & $\begin{array}{c}\text { Median } \\
\text { Year }\end{array}$ & $\begin{array}{c}\text { Median } \\
\text { Expense } \\
\text { Ratio }\end{array}$ & $\begin{array}{c}\text { Average } \\
\text { Expense } \\
\text { Ratio }\end{array}$ & $\begin{array}{c}\text { Median } \\
\text { Annualized } \\
\text { Return }\end{array}$ & $\begin{array}{c}\text { Average } \\
\text { Annualized } \\
\text { Return }\end{array}$ & $\begin{array}{c}\text { Median } \\
\text { NAV } \\
\text { (millions) }\end{array}$ & $\begin{array}{c}\text { Median } \\
\text { Turnover } \\
\text { Ratio }\end{array}$ & $\begin{array}{c}\text { Average } \\
\text { Fund Age } \\
\text { (years) }\end{array}$ \\
\hline \multicolumn{10}{|l|}{ By Category: } \\
\hline ETF & $1,844,683$ & 2014 & $0.46 \%$ & $0.44 \%$ & $19.97 \%$ & $12.88 \%$ & 39.37 & 0.22 & 12.36 \\
\hline Mutual Fund & $39,442,121$ & 2010 & $1.29 \%$ & $1.36 \%$ & $20.21 \%$ & $10.32 \%$ & 14.92 & 0.61 & 15.99 \\
\hline \multicolumn{10}{|l|}{ By Fund Type: } \\
\hline Active & $1,179,273$ & 2011 & $1.24 \%$ & $1.32 \%$ & $18.52 \%$ & $9.67 \%$ & 13.79 & 0.58 & 13.31 \\
\hline Passive & $40,107,531$ & 2010 & $1.25 \%$ & $1.22 \%$ & $20.24 \%$ & $10.46 \%$ & 15.39 & 0.59 & 15.90 \\
\hline \multicolumn{10}{|c|}{ By Current Status: } \\
\hline Live Funds & $24,753,127$ & 2013 & $1.12 \%$ & $1.16 \%$ & $21.60 \%$ & $13.00 \%$ & 17.42 & 0.51 & 18.04 \\
\hline Dead Funds & $16,533,677$ & 2006 & $1.50 \%$ & $1.56 \%$ & $17.61 \%$ & $6.62 \%$ & 13.05 & 0.72 & 12.51 \\
\hline All funds & $41,286,804$ & 2010 & $1.25 \%$ & $1.32 \%$ & $20.19 \%$ & $10.44 \%$ & 15.33 & 0.59 & 15.82 \\
\hline
\end{tabular}

Our dataset consists of 41,286,804 daily fund observations, spanning 1998 to 2019. In 1998, CRSP began reporting daily returns data. CRSP's adaptation coincides with the earliest observations retained in our data set. We perform transformations on 21 variables and have approximately 20,000 unique CRSP fund numbers that map to approximately 46,000 unique funds in our dataset. ${ }^{37,}, 38$ Mutual funds make up the majority of our observations as ETFs are still in their nascent stage. Median returns for ETFs and mutual funds are similar at approximately $20 \%$; however, average yearly returns are higher for ETFs at approximately $12.88 \%$ while mutual funds' average yearly returns are $10.32 \%$. The difference, $2.56 \%$, is markedly large, especially for long-term investors. Over 10 years, this equates to approximately a 20\% difference in cumulative return. Expense ratios are much lower for ETFs than they are for mutual funds, further widening the gap between ETF and mutual fund returns. Both the average and median expense ratios for mutual funds are nearly three times larger than the expense ratios for ETFs. (Figure 6). Mutual fund turnover is approximately three times that of ETFs. Turnover may be a key factor driving the difference in expense ratios between fund types. The average age of mutual funds in our sample exceeds ETFs by approximately four years.

Passively managed funds outnumber actively managed funds in our sample. We find that fund characteristics across groups are similar though passive ETFs have higher average and median returns. Passive fund turnover is nearly identical to that of active funds. On average passive funds have lower expense ratios, which is in line with expectations. Approximately $60 \%$ of the funds in our sample are actively managed, while approximately $40 \%$ are no longer active. Dead funds, on average, have lower returns and higher expense ratios than live funds. Live funds are almost double the average yearly return of dead funds. The average lifespan of a dead fund is almost six years shorter than the lifespan of a live fund. This suggests that underperforming funds exit the market quickly. High turnover is associated with these funds, which may contribute to their higher costs.

In Table 3, we provide summary statistics for active and passive ETFs as well as active and passive mutual funds.

\begin{tabular}{|c|c|c|c|c|c|c|c|c|c|c|}
\hline $\begin{array}{c}\text { Fund Type by } \\
\text { Strategy }\end{array}$ & $\begin{array}{l}\text { Distinct } \\
\text { Funds }\end{array}$ & $\begin{array}{l}\text { Median } \\
\text { Year }\end{array}$ & $\begin{array}{c}\text { Median } \\
\text { Expense } \\
\text { Ratio }\end{array}$ & $\begin{array}{c}\text { Average } \\
\text { Expense } \\
\text { Ratio }\end{array}$ & $\begin{array}{l}\text { Median } \\
\text { Annualized } \\
\text { Return }\end{array}$ & $\begin{array}{c}\text { Average } \\
\text { Annualized } \\
\text { Return }\end{array}$ & $\begin{array}{l}\text { Median } \\
\text { NAV } \\
\text { (millions) }\end{array}$ & $\begin{array}{c}\text { Median } \\
\text { Turnover } \\
\text { Ratio }\end{array}$ & $\begin{array}{l}\text { Average } \\
\text { Fund } \\
\text { Age } \\
\text { (years) }\end{array}$ & $\begin{array}{l}\text { Live / Dead } \\
\text { Funds }\end{array}$ \\
\hline \multicolumn{11}{|l|}{ ETF } \\
\hline Active & 51 & 2017 & $0.75 \%$ & $0.71 \%$ & $22.69 \%$ & $20.76 \%$ & 31.20 & 0.58 & 4.07 & $43 / 8$ \\
\hline Passive & 1,165 & 2014 & $0.45 \%$ & $0.44 \%$ & $19.92 \%$ & $12.78 \%$ & 39.60 & 0.22 & 12.47 & 890 / 275 \\
\hline \multicolumn{11}{|l|}{ Mutual Fund } \\
\hline Active & 907 & 2011 & $1.25 \%$ & $1.33 \%$ & $18.43 \%$ & $9.43 \%$ & 13.63 & 0.58 & 13.50 & 392 / 515 \\
\hline Passive & 17,932 & 2010 & $1.29 \%$ & $1.36 \%$ & $20.26 \%$ & $10.35 \%$ & 14.98 & 0.61 & 16.06 & $8,106 / 9,826$ \\
\hline
\end{tabular}

Table 3. Time series of cross-sectional average and median annual attributes by fund type and strategy September 1999 to June 2019. 
Most funds in our sample are passive. We have 24,223 active ETFs and 1,820,460 daily passive ETF observations. For mutual funds, there are 1,155,050 active daily fund observations and 38,287,071 daily passive fund observations. These observations map to 51 active and 1,165 passive ETFs in addition to 907 active and 17,932 passive mutual funds that meet our criteria as described in Data and Variables Definitions.

Revisiting Figure 5, we must be careful in our assessment of active ETFs as its strong performance is drawn from a small sample of funds. Even so, these results should not be dismissed. Active ETFs are in their nascent phase. The first active equity ETFs, the PowerShares Active Alpha funds, commenced operations in 2008 and did not have a full calendar year of performance history until 2009. Whereas, State Street introduced the SPDR S\&P 500 Trust fund in 1993. This is evidenced by the average age of active ETFs; the average age of active ETFs is slightly over four years, while passive ETFs average age is 12.5 years. The first active ETF was introduced in 2008 by Bear Stearns; however, we exclude if from our analysis as it was not an equity-based fund. Table 3 supports our earlier findings that active ETFs have the highest returns. Passive ETFs, passive mutual funds, and active mutual funds follow in the stated order. This aligns with Figure 5, as we see that both ETFs categories outperform mutual funds on average. This is also shown in Table 2's comparison of ETFs and mutual funds.

In Figure 7, we plot yearly returns by fund type. Again we find that, on average, ETFs outperform mutual funds. We also note that both ETFs and mutual funds experience negative market shocks during the early 2000's bursting of the dot-com bubble and the 2008 Great Recession. Mutual fund returns were slightly more negative during these periods.

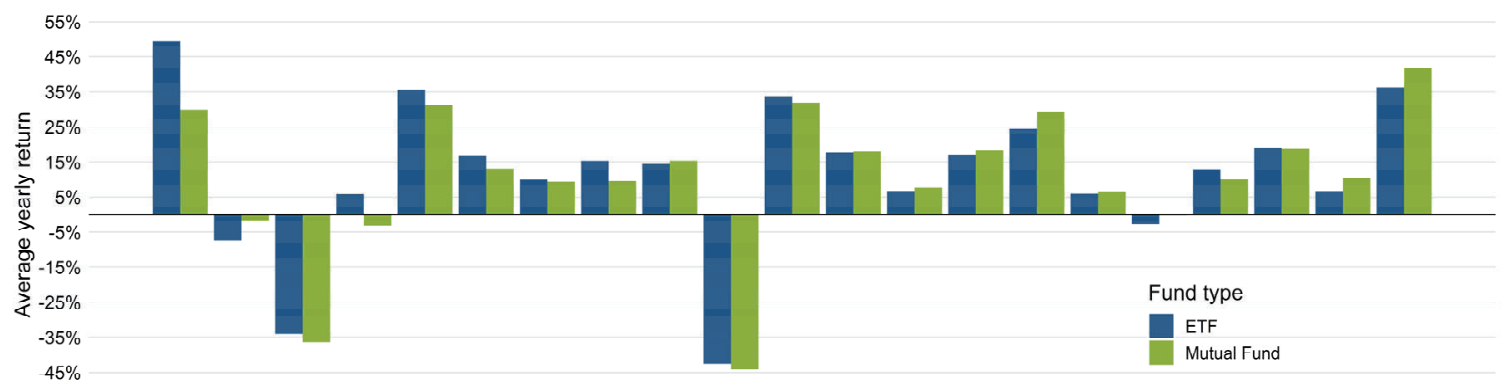

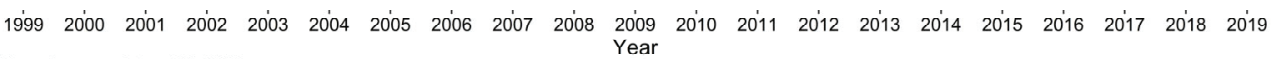
Note: 2019 numbers as of June 28,2019

Figure 7. Yearly Return by Fund Type.

Figure 8 provides a more detailed picture. Here, we separate funds by type and strategy. We add the SPDR S\&P 500 ETF (SPY) as a benchmark for performance. Active ETF observations begin with their introduction in 2009.

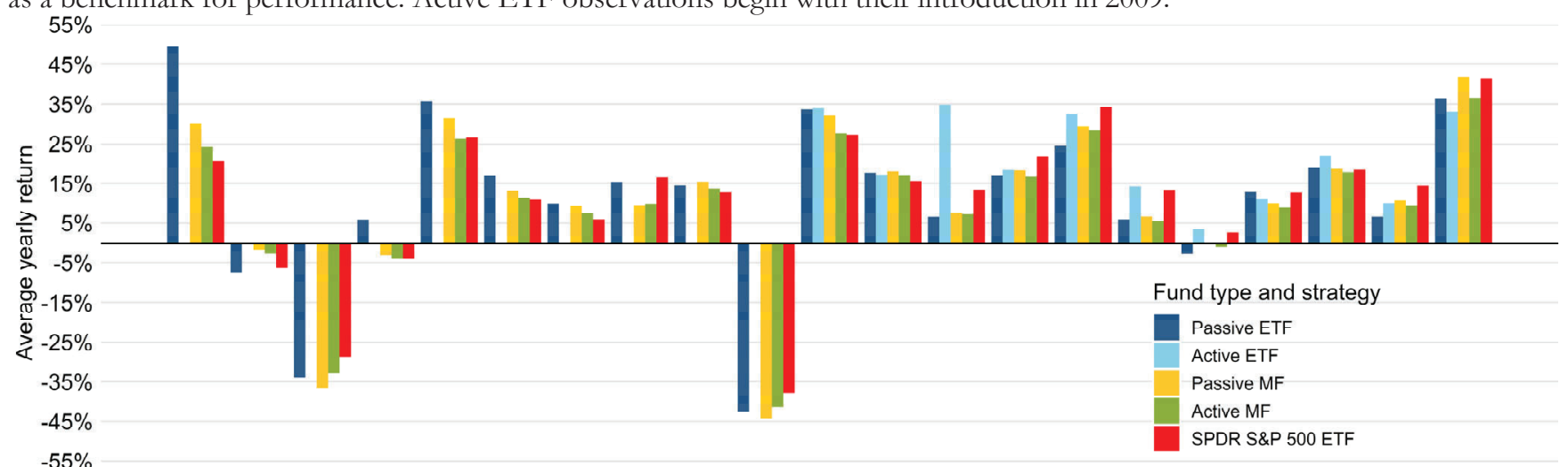

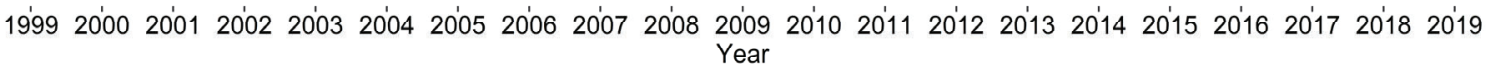

Figure 8. Yearly return by fund type \& strategy.

In Figure 8, we see that ETFs outperform mutual funds on average. Our benchmark fund is SPY, the first ETF introduced in 1993. From January of 1999 to June 2019, SPY had an average return of $10.74 \%$, exceeding the returns of active and passive mutual funds. However, SPY's median return of $16.88 \%$ is less than the median returns of all funds, meaning that over $50 \%$ of funds in our sample outperformed SPY. 
In Table 4, we look at performance during recessionary periods. Using the National Bureau of Economic Research's (NBER) business cycle expansion and contractions dates we restrict our sample to dates between March 2001 and November 2001 and between December 2007 and June 2009. ${ }^{39}$

\begin{tabular}{ccc}
\hline Fund Type by Strategy & Distinct Funds & $\begin{array}{c}\text { Average } \\
\text { Annualized } \\
\text { Return }\end{array}$ \\
\hline ETF $\quad$ Active & 2 & $24.68 \%$ \\
$\begin{array}{c}\text { Passive } \\
\text { Mutual Fund } \\
\text { Active }\end{array}$ & 392 & $-19.01 \%$ \\
Passive & 11,662 & $-23.33 \%$ \\
All Funds & & \\
Active & 418 & $-23.22 \%$ \\
Passive & 12,050 & $-24.14 \%$ \\
\hline Table 4. Fund performance during recessionary periods.
\end{tabular}

During recessionary periods ETFs outperform mutual funds, while active funds come out ahead of passively managed funds though not by much. Having a predetermined strategy, passive ETFs do not adjust in bear markets, whereas active fund managers may adjust their holdings to limit losses. During these periods, we expect actively managed funds to perform well relative to passively managed funds. Table 4 suggests that this explanation may be plausible though active funds sustain losses that are only slightly less than passive funds. It may be advantageous to invest in an actively managed firm during economic downturns. In 2009, the newly introduced PowerShares Active Alpha Q fund and the PowerShares Active Mega-Cap Fund performed well during the recessionary period; however, we cannot draw strong conclusions from such a limited sample. These funds enter our sample in January of 2009.

In Tables $\mathbf{5}$ and 6, we show our regression estimates for Equations $\mathbf{1}$ through $\mathbf{4}$ across fund types and strategies. Table $\mathbf{5}$ shows active and passive ETFs, while Table 6 presents active and passive mutual funds.

For passive ETFs, $\varphi_{1}$ is positive and statistically significant for Equations 1, 2, and 3. Equations 1 and 2 equate to our market and Fama French regressions in Table 5. For both, we estimate expense ratio coefficients that are statistically significant at the $1 \%$ confidence level. From Equation 3, we estimate Carhart's four-factor model finding an expense ratio coefficient that is significant at the 5\% level. Adding control variables to the Carhart model as in Equation 4 we find no significance for $\varphi_{1}$. For active ETFs, $\varphi_{1}$ is negative, but only statistically significant for the market regression ( $5 \%$ confidence level).

Multiplying this by the median expense ratio for passive ETFs found in Table 3, 0.44\%, we estimate that the median passive ETFs' expense ratio contributes a daily return gain of $0.015 \%$. The three-factor model coefficient rounds to the same gain while our four-factor model produces a daily gain of $0.013 \%$. Using the number of trading days in a year, we find that passive ETFs gain between $3.29 \%$ and $3.80 \%$ annually.

The expense ratio coefficients for active ETFs are negative; however, the market model is the only regression with a statistically significant coefficient. The market model expense ratio coefficient, -0.292 , is significant at 5\%. Using the median expense ratio for active ETFs, $0.71 \%$, we find that the median actively managed ETF has a daily reduction in NAV of $0.207 \%$ or $52.45 \%$ annually.

For active mutual funds, $\varphi_{1}$ is positive and statistically significant across all regressions. The coefficient is consistently 0.0259 for all regressions except for when we add controls to the four-factor model. With controls, the coefficient drops to 0.0247 . Using the median expense ratio for active funds, we estimate the yearly gains for investing in active mutual funds to be between $7.83 \%$ and $8.19 \%$ annually. For passive funds, $\varphi_{1}$ is not statistically significant in any of our models. Even so, the coefficient near zero for all the regressions, indicating that even if significant, the expense ratio would have no effect. 
Exchange-Traded Funds

\begin{tabular}{|c|c|c|c|c|c|c|c|c|}
\hline & \multicolumn{2}{|c|}{ Market } & \multicolumn{2}{|c|}{ Fama French } & \multicolumn{2}{|c|}{ Carhart } & \multicolumn{2}{|c|}{ Carhart Controls } \\
\hline & (1) & (2) & (3) & (4) & (5) & (6) & (7) & (8) \\
\hline & Active & Passive & Active & Passive & Active & Passive & Active & Passive \\
\hline MKTRF & $\begin{array}{c}0.878^{* * * *} \\
(25.40)\end{array}$ & $\begin{array}{c}0.906^{* * *} \\
(67.24)\end{array}$ & $\begin{array}{c}0.865^{* * *} \\
(28.69)\end{array}$ & $\begin{array}{c}0.882 * * * \\
(70.57)\end{array}$ & $\begin{array}{c}0.876^{* * * *} \\
(29.60)\end{array}$ & $\begin{array}{c}0.871^{* * *} \\
(70.24)\end{array}$ & $\begin{array}{c}0.866^{* * *} \\
(29.69)\end{array}$ & $\begin{array}{c}0.869^{* * *} \\
(69.87)\end{array}$ \\
\hline HML & & & $\begin{array}{c}0.0507 \\
(1.15)\end{array}$ & $\begin{array}{c}0.101 * * * \\
(6.93)\end{array}$ & $\begin{array}{l}0.0622 \\
(1.23)\end{array}$ & $\begin{array}{c}0.0567 * * * \\
(4.04)\end{array}$ & $\begin{array}{l}0.0623 \\
(1.23)\end{array}$ & $\begin{array}{c}0.0564^{* * *} \\
(4.03)\end{array}$ \\
\hline SMB & & & $\begin{array}{c}0.0932 \\
(1.75)\end{array}$ & $\begin{array}{c}0.106^{* * *} \\
(8.08)\end{array}$ & $\begin{array}{c}0.0981 \\
(1.89)\end{array}$ & $\begin{array}{c}0.102^{* * *} \\
(7.76)\end{array}$ & $\begin{array}{c}0.0985 \\
(1.90)\end{array}$ & $\begin{array}{c}0.100^{* * *} \\
(7.67)\end{array}$ \\
\hline UMD & & & & & $\begin{array}{c}0.0179 \\
(0.88)\end{array}$ & $\begin{array}{c}- \\
0.0660^{* * *} \\
(-13.08)\end{array}$ & $\begin{array}{c}0.0174 \\
(0.84)\end{array}$ & $\begin{array}{c}-0.0666^{* * *} \\
(-13.19)\end{array}$ \\
\hline EXP_RATIO & $\begin{array}{c}-0.292^{*} \\
(-2.18)\end{array}$ & $\begin{array}{c}0.0332 * * \\
(2.75)\end{array}$ & $\begin{array}{l}-0.273 \\
(-1.86)\end{array}$ & $\begin{array}{c}0.0319 * * \\
(2.67)\end{array}$ & $\begin{array}{l}-0.268 \\
(-183)\end{array}$ & $\begin{array}{c}0.0303^{*} \\
(2.55)\end{array}$ & $\begin{array}{l}-0.169 \\
(-1.00)\end{array}$ & $\begin{array}{c}0.0109 \\
(0.74)\end{array}$ \\
\hline DNAV & & & & & & & $\begin{array}{c}0.0000552 \\
(0.81)\end{array}$ & $\begin{array}{c}0.0000870^{* * *} \\
(5.24)\end{array}$ \\
\hline NAV_LATEST & & & & & & & $\begin{array}{c}-0.0000199 \\
(-0.39)\end{array}$ & $\begin{array}{c}- \\
0.0000821^{* * *} \\
(-4.92)\end{array}$ \\
\hline TNA_LATEST & & & & & & & $\begin{array}{c}- \\
0.000000283 \\
(-1.11)\end{array}$ & $\begin{array}{c}3.28 \mathrm{E}-10 \\
(0.43)\end{array}$ \\
\hline TURN_RATIO & & & & & & & $\begin{array}{c}-0.00000159 \\
(-0.13)\end{array}$ & $\begin{array}{c}0.0000587 \\
(1.76)\end{array}$ \\
\hline Constant & $\begin{array}{c}0.000572 \\
(0.35)\end{array}$ & $\begin{array}{c}-0.000479 \\
(-1.55)\end{array}$ & $\begin{array}{c}0.000409 \\
(0.24)\end{array}$ & $\begin{array}{c}-0.000284 \\
(-0.94)\end{array}$ & $\begin{array}{c}0.000420 \\
(0.25)\end{array}$ & $\begin{array}{c}-0.000165 \\
(-0.54)\end{array}$ & $\begin{array}{c}-0.000858 \\
(-0.53)\end{array}$ & $\begin{array}{c}-0.000224 \\
(-0.76)\end{array}$ \\
\hline Observations & 24223 & 1820460 & 24223 & 1820460 & 24223 & 1820460 & 24223 & 1820460 \\
\hline R-squared & 0.486 & 0.527 & 0.488 & 0.530 & 0.488 & 0.532 & 0.488 & 0.532 \\
\hline Fund Fixed Effects & yes & yes & yes & yes & yes & yes & yes & yes \\
\hline $\begin{array}{l}\text { Year Fixed Effect } \\
\text { Robust standard }\end{array}$ & yes & yes & yes & yes & yes & yes & yes & yes \\
\hline errors & yes & yes & yes & yes & yes & yes & yes & yes \\
\hline
\end{tabular}

$t$ statistics in parentheses

${ }^{*} p<0.05$, ** $p<0.01$, *** $p<0.001$

Table 5. ETF expense ratio on fund performance.

\section{DISCUSSION}

We show that returns for passive mutual funds and ETFs decrease as their expense ratios enter the upper decile range for their peer group (Figure 4). Breaking this finding down into management strategies, active and passive, we find that this result is not evenly distributed across subcategories. Active funds exhibit the opposite behavior, with returns increasing into the fifth decile. Passive ETF returns decrease in the first four decile groups (Figure 5). This behavior suggests that studies of ETF and mutual fund performance should account for the investment strategies of sampled funds. Failing to account for fund strategy may skew a study's findings based on the composition of the funds in the study. For example, a study of randomly selected ETFs that are tilted toward actively managed funds will result in higher returns than a randomly selected sample of ETFs that happens to be tilted toward passively managed funds, holding everything else constant. 


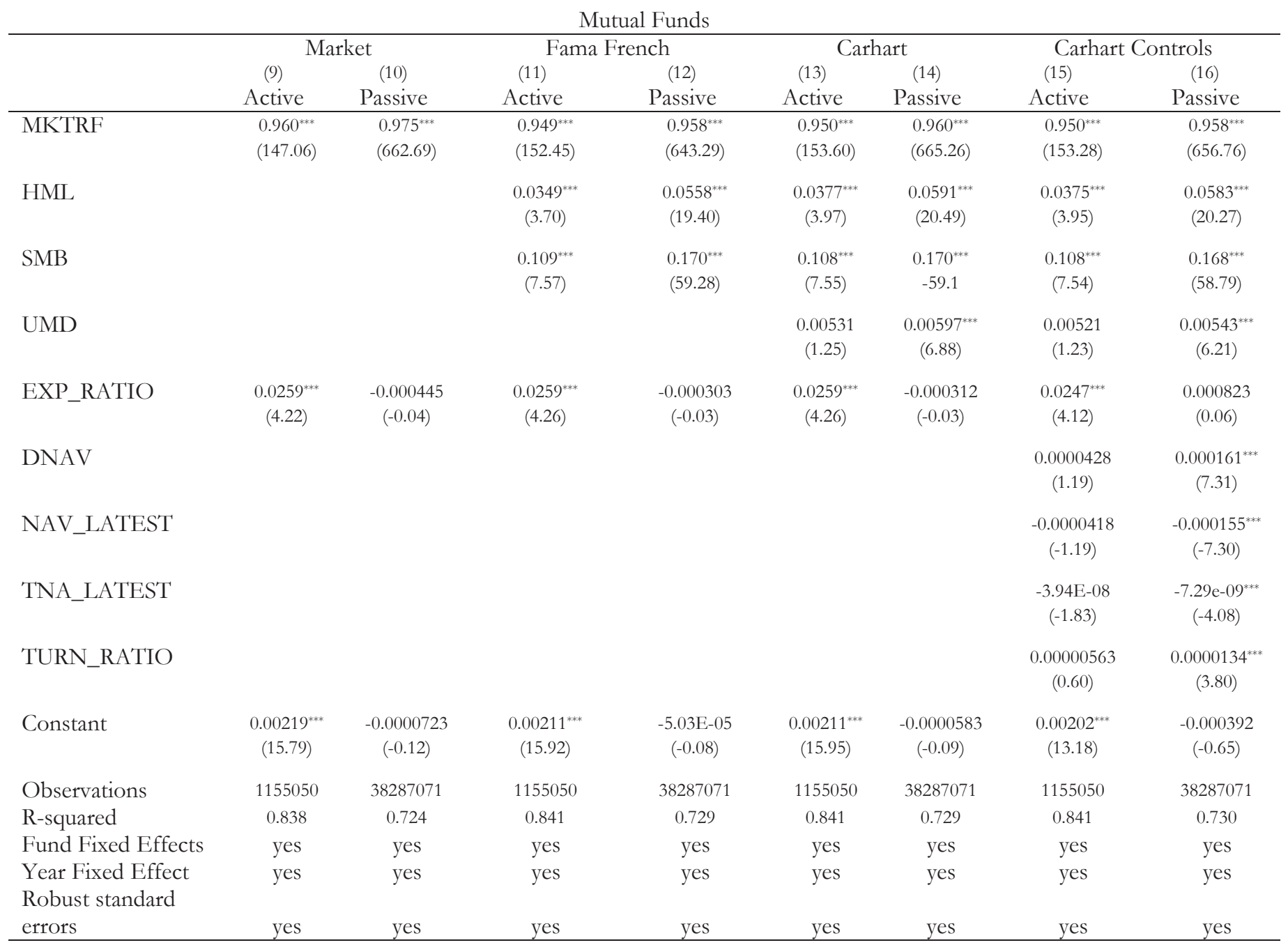

t statistics in parentheses

${ }^{*} p<0.05$, ** $p<0.01$, *** $p<0.001$

Table 6. Mutual fund expense ratio on fund performance.

In Figure 5, we show that active ETFs have higher returns across all decile groups which is confirmed in Table 3. We find that both average and median yearly returns are highest for active ETFs. Though we find that the performance of active ETFs has been stellar since their inception, the sample size is too small for us to conclude that their relative outperformance will continue. Since 2013, we have seen some signs of decline in their relative returns. The SPDR S\&P 500 ETF has produced similar returns during this period. In addition, Pástor, Stambaugh, and Taylor have shown that upward trends in skill in the mutual fund industry coincide with industry growth. As AUM increases, a fund manager's ability to outperform passive benchmarks declines. ${ }^{19}$ Young firms tend to outperform older funds, and as more firms enter the space competition will increase eroding performance. It is possible that the trajectory of the active ETF industry may follow a similar path.

We use the median expense ratio for each fund type found in Table 3 and multiply it by the coefficient $\varphi_{1}$ to estimate the median increase or decrease in daily returns dependent on fund strategy. We annualize this value to get the median change in returns for active and passive strategies. For passive ETFs, we estimate an increase between 3.29\% and 3.80\% annually. For active ETFs, the coefficient is large and negative suggesting a decrease in fund returns as the expense ratio increases. The market model is the only regression with a statistically significant expense ratio coefficient ( $5 \%$ confidence level). The magnitude $(52.45 \%)$ of the coefficient is abnormally large relative to our other regressions. This may be attributable to our limited number of active ETF observations. Even so, the coefficient suggests that there is a negative relationship between active ETF fees and returns.

So, which is better, active or passive management? In aggregate, passive funds outperform active funds. Table 2 shows that passive funds have higher average and median returns. Their median expense ratios are nearly identical; however, passive funds 
have lower average expense ratios. Figure 1 shows inflows into index-based ETFs and mutual funds while active mutual funds are experiencing negative outflows. This is likely attributable to active fund's underperformance of benchmark indices. Figure 8 shows that the SPDR S\&P 500 ETF has consistently outperformed active mutual funds for much of the sample.

We also sought to answer whether ETFs are better investment vehicles than mutual funds. In our analysis, we find that ETFs have the advantage of lower median expense ratios $0.75 \%$ to $1.25 \%$ and higher median returns from $22.69 \%$ to $18.43 \%$. Thus, broadly, ETFs are better investment vehicles. Sorting by fund type and strategy, we find that active ETF expense ratios are 35\% lower than active mutual funds expense while passive ETF expense ratios are 60\% lower than passive mutual funds. In Figure 6, we show a downward trend in mutual fund expense ratios and speculate that this trend will continue as mutual funds are forced to compete with ETFs on price. The mutual fund industry has traditionally charged more for its services, but this has begun to change (Table 3). Mutual funds may come with sales loads and account minimums that make it difficult for small investors to get started. ETFs offer transaction cost and liquidity advantages over mutual funds.

If passive funds outperform active funds and ETFs outperform mutual funds, does that mean passive ETFs are the best investment choice? This is a tricky question. For both ETFs and mutual funds, passive funds with high expense ratios perform worse than their lower-cost peers. If two funds are benchmarked to the same index, the fund with the higher expense ratio will provide lower returns if both funds' tracking error - the deviation from their underlying index - is the same. Rational investors should choose the index fund with the lowest expense ratio; however, Choi, Laibson, and Madrian have shown that investors do not always behave rationally when selecting between index funds. Thus, the market for high expense index funds will continue to exist irrespective of their underperformance. ${ }^{18}$

Innovation in business models, such as commission-free trades, has lowered the barrier of entry for ETFs and has increased their popularity. Past research looking at the dispersion of S\&P 500 returns attributes the dispersions of expense ratios across similar indices to search costs and financial literacy. ${ }^{18}$ Since this work, search costs have diminished and financial markets are easily accessible. Investigation needs to be done as to how commission-free trades affect the individual investor's long-term decisions. Additionally, prior studies that take brokerage costs into account when measuring performance need to be updated. By including transaction costs, previous authors did not anticipate financial innovations that allow for frictionless transactions.

We suspect that there is a relationship between the underperformance of active mutual funds and their net outflows. At their expense, passive funds have made tremendous gains in terms of AUM. As active mutual funds exit the market, only the strongest funds will survive. ${ }^{22}$ Our regression results show that actively managed mutual fund returns are positively correlated with their expense ratios, suggesting performance increases with management fees (Table 6). This positive correlation may be partially attributable to the fact that, for active investors, skill plays a major role in whether a fund outperforms index-funds. Funds with strong performance can charge more because they deliver higher returns.

This may be explained by investor willingness to pay for skill. In an efficient market, higher-skilled managers will make more than those with lesser skills. Berk and Green theorize that the AUM can predict a mutual fund manager's skill. Berk and Green hypothesize that investors are only willing to invest, given a fund has a positive managerial burden greater than zero. Devoid of value-added, investors would not invest in managers whose burden was less than zero (equates to negative return).

\section{Managerial Burden = Manager Compensation \pm Money Made (or taken)from investers}

Employing Berk and Green's equation for active funds, we estimate that until the critical juncture where returns are nullified by managerial burden, active managers will be compensated based on skill. We also conclude that an active mutual fund manager's compensation is more representative of their skill level than an active ETF manager. This is primarily because our regression results are based on fewer funds over a shorter period.

For passive mutual funds, our expense ratio coefficients are near zero and not significant (Table 6). This can be interpreted in several ways. One interpretation may be that passive fund managers do not add any value. Alternatively, it can be interpreted as a manager doing their job neither outperforming nor underperforming their benchmark index. One would expect excess portfolio returns to be at or near zero if a fund is tracking the broader market.

Lastly, we looked at recessionary periods to determine if active funds performed better than passive funds, with the hypothesis being that active funds can take actions to mitigate losses. We found that, overall, actively managed mutual funds have fewer losses, suggesting that it may be wise to switch into actively managed mutual funds during these periods. More work needs to be done to fully examine this strategy, though we show that it is worth studying. We do not have sufficient information to reach a 
conclusion about active ETFs. They did not exist during the 2000's recession and there were only two in our sample at the time of the Great Recession. Lastly, we note that all funds were affected by the recessions; thus, none of the fund strategies are recessionproof.

\section{CONCLUSION}

Our focus on expense ratios and performance show that high expense funds must yield higher returns to offset costs born to investors. From 1998 to 2019, there has been downward pressure on mutual fund expense ratios coinciding with the introduction and rise of ETFs as investment alternatives. On average, ETFs outperform mutual funds and passive index-based funds outperform actively managed funds. Individually, active ETFs have generated the highest median returns; however, they were not introduced until 2009. It remains to be seen whether the strong performance of active ETFs will continue as the industry matures.

Our results show that passive funds perform better than active funds, which is why we believe money is flowing from underperforming actively managed domestic equity mutual funds into index domestic ETFs and mutual funds. ETFs have seen the largest inflows and have the highest returns. Passive mutual funds have outperformed active mutual funds but have seen fewer returns than passive ETFs. Thus, it follows that domestic equity index ETFs have had higher outflows.

Since 2003 mutual fund expenses have declined (Figure 4). We believe this to be an attributable effect of the introduction of ETFs into the marketplace. ETFs, on average, have much lower expenses than mutual funds. The downward trend of mutual funds is best explained by the exit of high-cost funds from the market and a shift from high-cost active mutual funds to passively managed mutual funds.

More research is needed to determine performance under extreme market pressures. From our data, we show a slight divergence in performance between mutual active and passive funds during periods of recession. This is likely attributable to an actively managed fund's ability to change investment strategies, whereas passive index funds follow persistent investment strategies despite market fluctuations. Further research should look to characterize other indicators of manager skill and their effect on active management strategies.

\section{ACKNOWLEDGEMENTS}

The author thanks mentor Dr. Shastri Sandy as well as Ray Bacon and Anna Wojcicki for their contributions to this work. The author thanks the University of Missouri McNair Scholars Program for its support in making this project possible.

\section{REFERENCES}

1. Agapova, A. (2011) Conventional mutual index funds versus exchange-traded funds, Journal of Financial Markets 14(2), 323343. https:// doi.org/10.1016/j.finmar.2010.10.005

2. Investment Company Institute. (2019) 2019 Investment Company Fact Book 59th ed., Investment Company Institute. bttps:/ / www.ici.org/pdf/2019_factbook.pdf

3. Guedj, I., \& Huang, J. C. (2009) Are ETFs Replacing Index Mutual Funds? In AFA 2009 San Francisco Meetings Paper, https:// dx.doi.org/10.2139/ssm.1108728

4. Poterba, J. M., \& Shoven, J. B. (2002) Exchange-Traded Funds: A New Investment Option for Taxable Investors, American Economic Review 92(2), 422-427. https:/ / www.aeaweb.org/articles?id=10.1257/000282802320191732

5. Bergstresser, D., Chalmers, J. M. R., \& Tufano, P. (2009) Assessing the Costs and Benefits of Brokers in the Mutual Fund Industry, The Review of Financial Studies 22(10), 4129-4156. http:/ / doi.org/10.1093/rfs/ hhp022

6. Council of Economic Advisers (2015) The effects of conflicted investment advice on retirement savings, http:/ / purl.fdlp.gov/GPO/gp055500 (accessed Oct 2019)

7. Securities and Exchange Commission, Press Release: SEC Adopts Rules and Interpretations to Enhance Protections and Preserve Choice for Retail Investors in Their Relationships With Financial Professionals, sec.gov/news/press-release/2019-89 (accessed Oct 2019)

8. $\quad 115^{\text {th }}$ Congress (2017) Public Law 115-97, https:// www.congress.gov/115/plaws/publ97/PLAW-115publ97.pdf

9. The White House, FACT SHEET: Middle Class Economics: Strengthening Retirement Security by Cracking Down on Backdoor Payments and Hidden Fees, https:// obamawhitehouse.archives.gov/ the-press-office/2015/02/23/fact-sheet-middle-classeconomics-strengthening-retirement-security-crac (accessed Oct 2019)

10. United States Securities and Exchange Commission, Mutual Fund Fees and Expenses, https:/ / wmw.sec.gov/fastanswers/ answersmffeeshtm.html (accessed Oct 2019)

11. Jaffe, C. (2008) Bear Stearns Current Yield (YYY), The Seattle Times, https:// wmw.seattletimes.com/business/bear-stearns-currentyield-yyy/ (accessed Oct 2019) 
12. French, K. R. (2008) Presidential Address: The Cost of Active Investing, Journal of Finance, 63(4), $1537-1573$. https://doi.org/10.1111/j.1540-6261.2008.01368.x

13. Chung, J., Sensoy, B., Stern, L., Weisbach, M. (2012) Pay for Performance from Future Fund Flows the Case of Private Equity, Review of Financial Studies 25(11), 3259-3304. https:/ / doi.org/10.1093/rfs/ hbr141

14. Holmström, B. (1999) Managerial Incentive Problems: a Dynamic Perspective, The Review of Economic Studies 66(1), $169-182$. https://doi.org/10.1111/1467-937X.00083

15. Berk, J. B., Green, R. (2004) Mutual Fund Flows and Performance in Rational Markets, Journal of Political Economy 112(6), 1269-1295. https:// www.journals.uchicago.edu/doi/abs/10.1086/424739

16. Berk, J. B., Van Binsbergen, J. H. (2015) Measuring skill in the mutual fund industry, Journal of Financial Economics 118(1), 120. https:// doi.org/10.1016/j.jfineco.2015.05.002

17. Lim, J., Sensoy B., Weisbach, A. (2016) Indirect Incentives of Hedge Fund Managers, The Journal of Finance 71(2), 871-918. bttps:// doi.org/10.1111/jofi.12384

18. Choi, J. J., Laibson, D., Madrian, B. C. (2010) Why Does the Law of One Price Fail? An Experiment on Index Mutual Funds, The Review of Financial Studies 23(4), 1405-1432. https:/ / doi.org/10.1093/rfs/ hhp097

19. Pástor, L., Stambaugh, R. F., Taylor, L. A. (2015) Scale and Skill in Active Management, Journal of Financial Economics 116(1), 23-45. https:// doi.org/10.1016/j.jfineco.2014.11.008

20. Hortaçsu, A., Syverson, C. (2004) Product Differentiation, Search Costs, and Competition in the Mutual Fund Industry: A Case Study of S\&P 500 Index Funds, The Quarterly Journal of Economics 119(2), 403-456. https:// doi.org/10.1162/0033553041382184

21. Wharton Research Data Services, CRSP Mutual Funds, wrds.wharton.upenn.edu (accessed Oct 2019)

22. Brown, S. J., Goetzmann, W., Ibbotson, R. G., Ross, S. A. (1992) Survivorship Bias in Performance Studies, The Review of Financial Studies 5(4), 553-580. https:// doi.org/10.1093/rfs/5.4.553

23. Brown, S. J., Goetzmann, W. (1995) Performance persistence, Journal of Finance 50(2), 679-698. https:// doi.org/10.1111/j.1540-6261.1995.tb04800.x

24. Carhart, M. (1997) On persistence in mutual fund performance, Journal of Finance 52(1), 57-82._https://doi.org/10.1111/j.15406261.1997.tb03808.x

25. Daniel, K., Grinblatt, M., Titman, S., Wermers, R. (1997) Measuring Mutual Fund Performance with Characteristic-Based Benchmarks, The Journal of Finance 52(3), 1035-1058. https:// doi.org/10.1111/j.1540-6261.1997.tb02724.x

26. Evans, R. B. (2010) Mutual Fund Incubation, Journal of Finance 65(4), 1581-1611. https://doi.org/10.1111/j.15406261.2010.01579.x

27. First Bridge Data, List of active ETFs (US Listed ETFs), https:// firstbridgedata.com/page/ list-of-active-etfs (accessed Oct 2019)

28. NASDAQ, Nasdaq's List of Fifth Character Symbol Suffixes, https:// www.nasdaqtrader.com/ content/technicalsupport/specifications/dataproducts/nasdaqfifthcharactersuffixlist.pdf (accessed Oct 2019)

29. Center for Research in Security Prices, Survivor-bias-free U.S. Mutual Fund Database Guide, http:/ / www.crsp.com/files/MF_Sift_Guide.pdf (accessed Sep 2019)

30. Morningstar Inc., Morningstar Investing Glossary, https:// wmw.morningstar.com/InvGlossary/ (accessed Oct 2019)

31. Stock, J., Watson, M. (2015) Interactions between Independent Variables, in Introduction to Econometrics 3rd ed., 278-287, Pearson Education, New Jersey.

32. Fama Jr., E., Multifactor Investing, https://www.ifa.com/academic-papers/multifactor_investing_eugene_fama_2006.pdf (accessed Oct 2019)

33. Fama, E., French, K. (1993) Common risk factors in the returns on stocks and bonds, Journal of Financial Economics 33(1), 356. https:/ / doi.org/10.1016/0304-405X(93)90023-5

34. Wharton Research Data Services, Fama-French Factors, wrds.wharton.upenn.edu (accessed Oct 2019)

35. French, K., Data Library, bttps:// mba.tuck.dartmouth.edu/pages/faculty/ken.french/data_library.btml (accessed Oct 2019)

36. Bernstein, W. J., Rolling Your Own: Three-Factor Analysis, http:// www.efficientfrontier.com/ ef/ 101/ roll101. htm

37. Foundation for Statistical Computing (2019) R, Version 3.6 for Windows

38. StataCorp (2015) Stata Statistical Software, Release 14

39. National Bureau of Economic Research, US Business Cycle Expansions and Contractions, https://www.nber.org/cycles.html (accessed Oct 2019)

\section{ABOUT THE STUDENT AUTHOR}

James Monroe Gamble IV is a senior at the University of Missouri pursuing a Bachelor of Science in Business Administration with an emphasis in Economics and a minor in mathematics. After graduating, James plans to attend graduate school to obtain a Ph.D. in economics with interests in financial markets and household finance. Long-term, James sees himself becoming a professor and renowned economics researcher. 


\section{PRESS SUMMARY}

In this study, we examine the impact of the emergence of Exchange Traded Funds (ETFs) as alternative investment vehicles to mutual funds. We compare ETF returns, performance, and expense ratios to those of mutual funds. We find over time an increased correlation between mutual fund fees and ETF fees and attribute this relationship to increased competition between mutual funds and ETFs. We also find up to a certain threshold, actively managed funds are worth their costs. 